\title{
15. Dugong Hunting as Changing Practice: Economic engagement and an Aboriginal ranger program on Mornington Island, southern Gulf of Carpentaria
}

\author{
Cameo Dalley
}

\section{Introduction}

Chapters in this volume and papers in a special edition of The Australian Journal of Anthropology in 2009 address the intersection of anthropology with economics. A particular focus has been the ways in which Indigenous cultures might relate to conceivably more foreign notions of market economies. One prominent example, which conceptualised Aboriginal engagements in economic enterprise, was the 'hybrid economy' model offered by Altman (2001). The model featured three intersecting realms: the 'market', the 'state' and the (Aboriginal) 'customary economy'. Important components of hybridity were the 'linkages', 'dependencies' and 'cleavages' between the various realms, which created particular opportunities, Altman (2001:5) argued, for economic development. Others, however, such as Martin (2003:3) and Merlan (2009:276), questioned the capacity of such sectors to exist in any way autonomously, instead pointing to their 'recursive' and 'interrelated' natures. These themes were similarly evident in the ethnographically rich analyses of local forms of economic relations by Austin-Broos (2003) and Smith (2003).

These explorations in economic anthropology draw heavily on broader discourses about the degree to which Aboriginal culture could be considered to exist autonomously from the culture of broader Australia. These discussions were particularly advanced by the contributions of Merlan (1998, 2005, 2006). Merlan's ethnography of the Aboriginal people of Katherine in the Northern Territory led her to propose a model of Aboriginal culture as having been transformed through interaction with others and, thus, having become thoroughly 'intercultural'. In Merlan's model, Aboriginal practice did not arise from an Aboriginal consciousness alone, but through its firm embedding within a broader cultural milieu (Merlan 2006:180). Merlan's work on the intercultural and the work of those who followed (for example, Hinkson and Smith 2005; 
Holcombe 2005; Smith 2003) inform analysis of the case study presented here: Aboriginal hunting of dugong (Dugong dugon) in the remote Aboriginal community of Mornington Island in the southern Gulf of Carpentaria.

Indigenous hunting is particularly relevant to discussions about economic anthropology and the intercultural because of the obvious changes that have occurred to practice, as exemplified by hunting material culture (Altman 1987; Merlan 2009:277-8). In some instances at least, a range of handcrafted Aboriginal hunting implements and techniques has been replaced with the use of rifles, motor vehicles and aluminium dinghies with outboard motors. This situation is further complicated because some of the species targeted are considered rare or endangered but Aboriginal people's rights to hunt some of these species are recognised under the Native Title Act 1993 (Cwlth). For some, hunting protected species is seen as incompatible with the ethos of the 'state' in this case, the Australian Government - to preserve places and species of high environmental and biodiversity value (Department of the Environment, Water, Heritage and the Arts 2008). Aboriginal hunting is, therefore, an example of what Gudeman (2001:1) described as the unification of culture with economy - a 'shifting relation, filled with tension'.

In the case study from Mornington Island, I focus on two intersecting points. The first of these is a historical perspective on dugong hunting as an intercultural practice. This approach accords with the notion of economies as local and specific, informed by ongoing and iterative engagements between Aboriginal people and others. In this first portion of the chapter, I engage with the local and changing nature of hunting as a practice. In the latter half, I turn my attention to the 'social relationships and contextually defined values' (Gudeman 2001:1) of hunting in the more recent period, as crafted by the media, conservation biologists, the Australian Government and the Wellesley Islands Rangers, an Aboriginal Ranger program based on Mornington Island. I show that the Rangers' perceptions of issues in dugong management do not necessarily equate with those of the Australian Government, which provides funding for their employment (see also Yanner 2008). Using interviews undertaken between 2007 and 2009, I demonstrate how the Rangers' concerns about hunting relate to the management of social relations guiding hunting more than species conservation per se. In their positions as rangers, the men seek to mediate discontinuities between these socially derived concerns and those of a conservation ethic through the adoption of 'management speak' (Babidge et al. 2007:153) as a form of 'strategic engagement' (Martin 2003:8). 


\section{Dugong Hunting as an Intercultural Practice}

In 1913 the Queensland Government approved an application from the Presbyterian Church to establish a mission on Mornington Island in the southern Gulf of Carpentaria (see Map 15.1). The application followed years of reports that the Aboriginal inhabitants of Mornington and the surrounding Wellesley Islands were being exploited by White traders seeking labour for their bêche-demer and pearl-shell enterprises (Harrison 1974; Loos 1982; White 1994:11). At the time, Mornington Island and the surrounding North Wellesley Islands were occupied by an estimated 400 Aboriginal people (Howard 1910) of the Lardil and Yankgaal language groups. In 1914, Reverend Robert Hall, who had been working in other Presbyterian missions on western Cape York, collected a ship from Thursday Island and sailed to Mornington to establish the first mission (Hall, 14 July 1914).

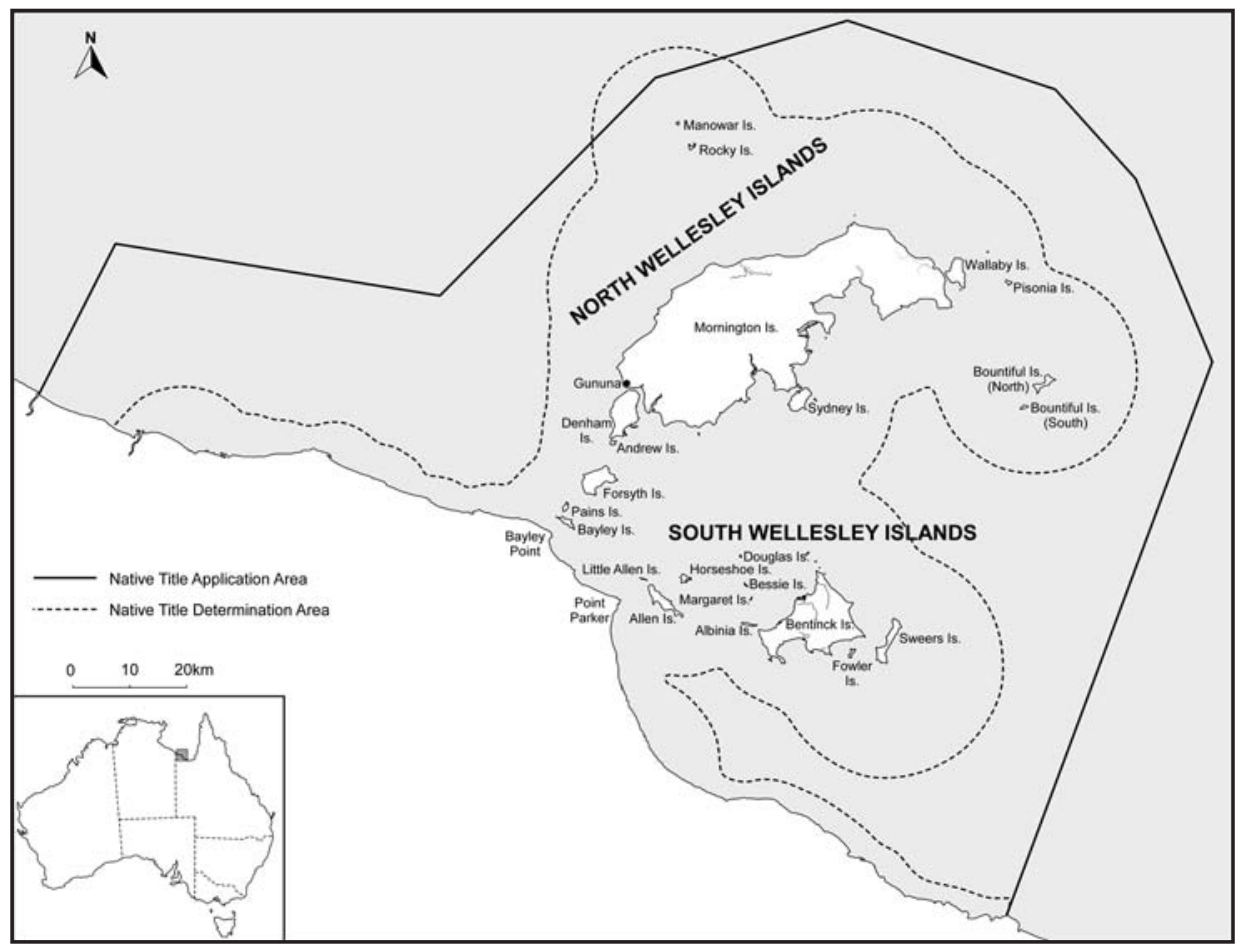

Map 15.1 Map of the southern Gulf of Carpentaria showing the areas in the application and those determined under the Wellesley Sea Claim (National Native Title Tribunal 2005). Note that the application and determination area extended only as far as the high-tide mark on land

Source: Sean Ulm. 
During the journey, Hall acquired six Aboriginal staff from missions on western Cape York, who would serve both as crew on the mission sailboat and as staff and labourers in the establishment of the mission. ${ }^{1}$ Within days of the party's arrival on Mornington Island, local Aboriginal people - primarily Lardil but also some Yangkaal people who journeyed across from neighbouring Denham Island-showed interest in the mission and began camping nearby (Hall, 2 June 1914, 23 July 1914). With little in the way of food, Hall set out to secure local Aboriginal labour to run a market garden. In order to pay local Aboriginal people for their work, Hall often sent the Cape York staff to hunt for dugong in the $12 \mathrm{ft}$ (approximately $3.6 \mathrm{~m}$ ) mission rowboat, shown in Figure 15.1 (Hall, 30 July 1914, 4 March 1915, 2 March 1916). In one such instance, after the mission had been operational for less than a month, more than 100 of the local Aboriginal residents came to work around the mission (Hall, 29 July 1914). Hall 'paid' the workers with a whole dugong, which the Cape York staff had hunted and cooked 'kapai Maori'² style (Hall, 30 July 1914). The hunting techniques and material culture used by the Cape York staff were markedly different from those of the local Lardil and Yangkaal Aboriginal people.

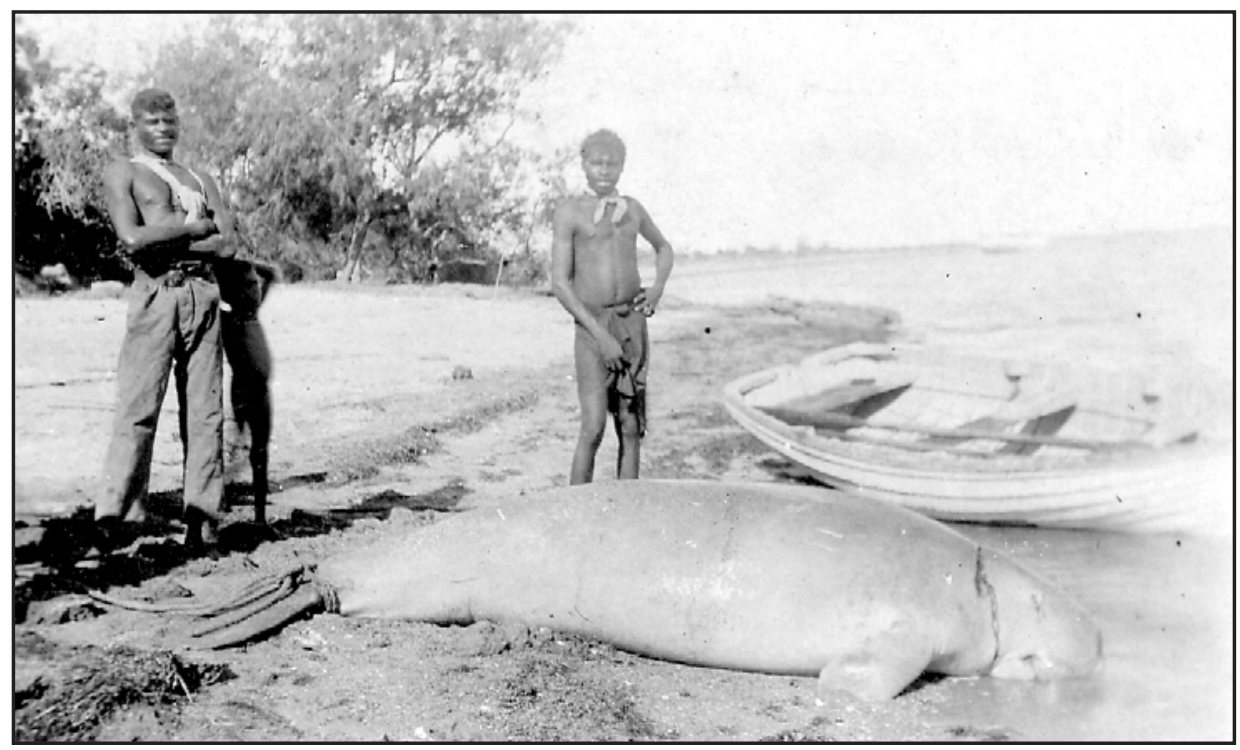

Figure 15.1 Dugong caught in the Appel Channel between Mornington Island and Denham Island, showing the mission rowboat used for hunting, 1916

Photo: Reverend Robert Hall, Hibberd Library collection.

1 Hall notes the first four crew members in his diary as Bertie, Bosin and Goodman (from Weipa) and Captain Henry Lewis (possibly a Torres Strait Islander) collected from Thursday Island (Hall, 9 April 1914, 20 April 1914). Along the journey from Thursday Island to Mornington Island, Hall also acquired another three crew members: Cockatoo and Wilkie (both from Batavia River) collected from Mapoon Mission (Hall, 25 April 1914) and Willie, an 'Aurukun boy', collected from the Aurukun Mission (Hall, 5 May 1914).

2 Hall was a New Zealander; however, there is no evidence to suggest that he undertook mission work with Maori. 
Prior to Hall's arrival, large groups of Lardil and Yangkaal Aboriginal people hunted dugong (dilmirrur) and sea turtle (bararun) (McKnight 1999:128). A net, such as the one shown in Figure 15.2, was placed at the end of a channel at low tide with two supporting poles pushed deep into the ground. Men on walbas (see Figure 15.3), a raft made of small buoyant logs lashed together at one end using rope made from hibiscus-tree fibre, would herd the dugongs towards the net (Memmott 2010:12; Smart 1951:34). Other men ran through the shallows along the beach splashing the surface of the water (Memmott 1979:163). With its exit routes blocked, the dugong would be forced into the net, become entangled and drown and/or be speared by the men waiting in the shallows (Cawte 1972:17; Smart 1951:35). This hunting approach required a large, organised group of people, and specialised dugong and turtle-hunting camps were convened for this purpose at particular places along the coastline (Memmott 1983:52).

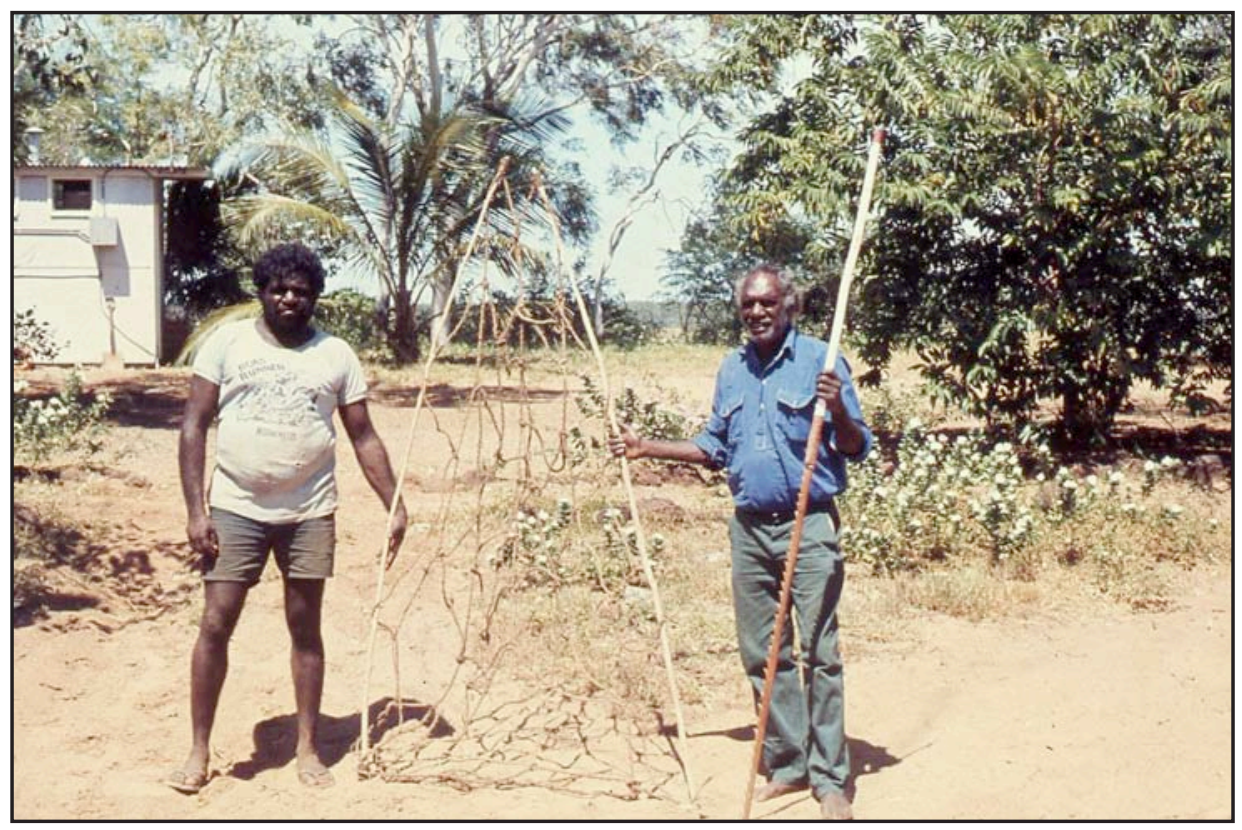

Figure 15.2 Brian Roughsey and Prince Escott (both deceased) with a modern reconstruction of a net used for catching dugong, 1976

Photo: George Heinsohn.

Along with this communal hunting approach came a structured system for the distribution of dugong meat for consumption, as recently described by Cyril Moon, a senior Lardil man:

But he fit for that camp, that one meat [dugong]. And them old people, he bin just know to slice'im and share the meat la one 'nother. That's before. He [the dugong hunter] bin cut'im dugong how he bin learn 
to cut'im that dugong, in his forefather time, great great [grandfather]. Same way, he cut'im like that, same way. He pass it [pieces of dugong meat] to people. He pass it lang his family, his countrymen. You can't tell him [what you want], bluff him. He no blind man when he pass'im. That 'un go right round that big whole camp. (Interview, 1 September 2007)

This system involved dedicated parts of the dugong being allocated to particular people, such as to those individuals (known as dulmadas in the Lardil language) who owned the country where the dugong was killed (Memmott and Trigger 1998:119).

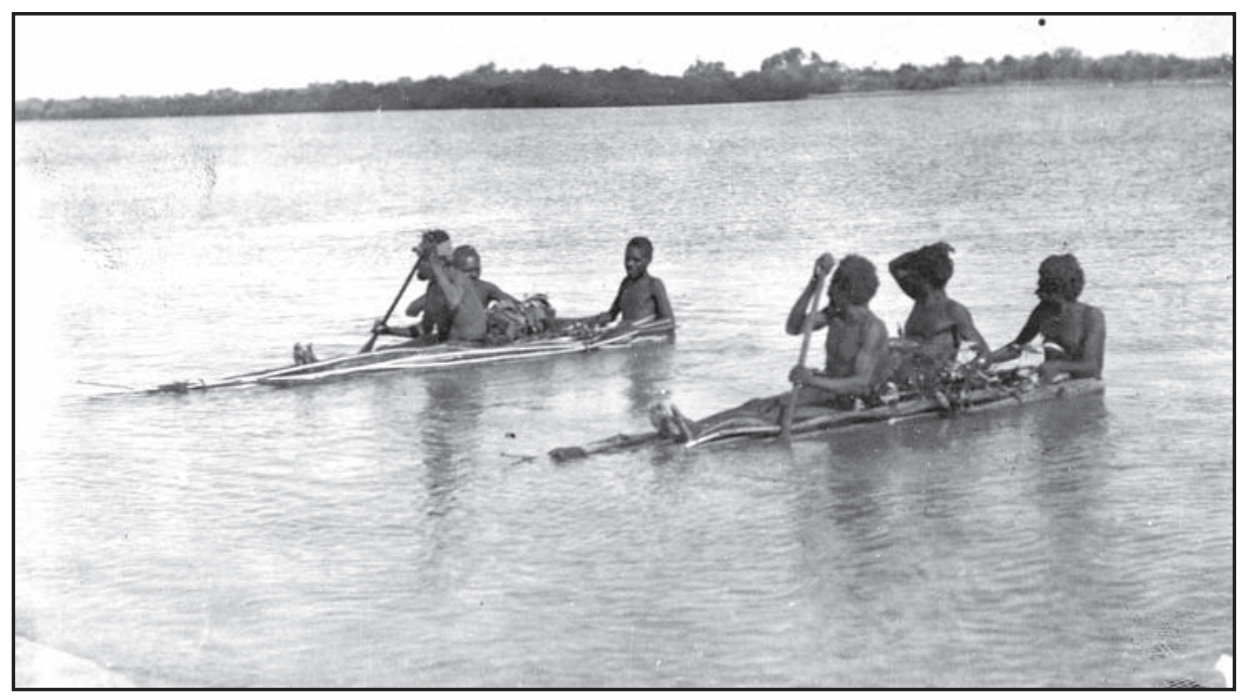

Figure 15.3 Walbas in the Appel Channel between Mornington Island and Denham Island

Photo: Image 214, Fryer Library Pictorial Collection, UQFL477, Fryer Library.

The raft technology used in the Wellesley Islands differed substantially from the bark and dugout canoes used by Aboriginal neighbours on the adjacent mainland (Bradley 1997:273-302; Davidson 1935:138-9; Trigger 1987:80). There are no records suggesting that either bark or dugout canoes were in use or manufacture in the Wellesleys prior to the arrival of missionaries (Davidson 1935:73, 80). On his arrival on Mornington, Hall (6 June 1914) commented that 'some native men came out to the boat on a raft - their only boat'. In his summary of Australian Aboriginal watercraft, Davidson (1935:139, 143-4) suggests that the raft found in the Wellesleys was an older form of watercraft that in most other parts of Australia was superseded by either bark or dugout canoes. One potential explanation for retention of the raft is the limited availability of tree species in the Wellesleys suitable in size or bark type for the manufacture of other types of watercraft (Memmott 2010:91; Trigger 1987). 
Hall's Aboriginal mission staff from western Cape York, however, were more familiar with dugong hunting from a dugout canoe or dugout outrigger ${ }^{3}$ canoe (see Figure 15.4), as was ubiquitous in Cape York at this time (Davidson 1935:713). As detailed in Donald Thompson's (1934:243-4) The Dugong Hunters of Cape York, hunting from a dugout relied on the use of a whap (a generic term from Torres Strait): a spear with a detachable head of up to three prongs (referred to by Mornington Islanders as the thartha) ${ }^{4}$ attached to a long rope. This approach involved a minimum of three people, usually men: one to row the canoe, one to use the whap and a third person to assist the others, arrange the rope and remove any entanglements (Hall 1986:93). The rigidity of the canoe formed a sturdy platform from which to force the whap into the back of the dugong and for the thartha to embed under the dugong's skin. The hunter could then hold onto the rope until the dugong tired, and it could be pulled beside the boat and drowned (Hall 1986:93; Thompson 1934:246). When Aboriginal people were introduced to wooden rowboats, the hunting method remained much the same.

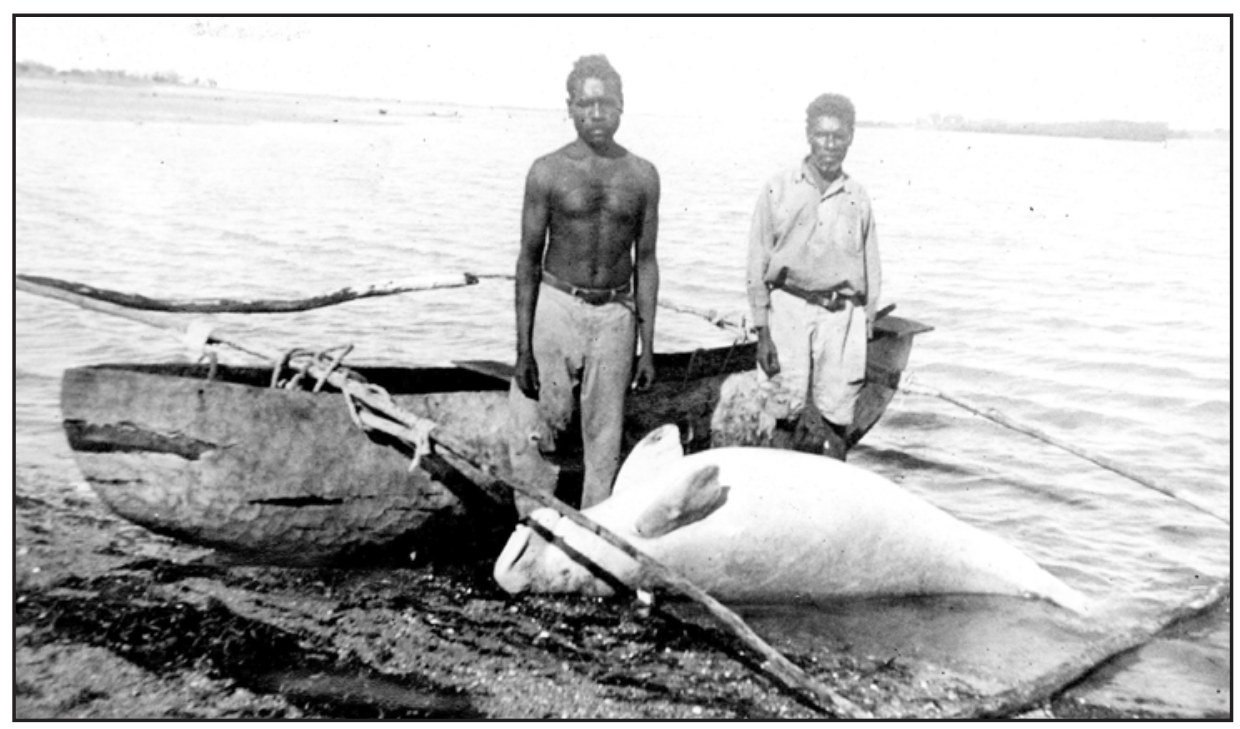

Figure 15.4 Dugong caught by Robert Burns and George Dugong (both deceased), showing double outrigger canoe used for hunting, Mornington Island, circa 1921

Photo: UQ Anthropology Museum, University of Queensland.

During Hall's three years at the Mornington Island mission, local Aboriginal people accompanied the Cape York staff out on hunting trips, learning the methods themselves. Over a relatively short period from 1914, whaps and

\footnotetext{
3 An outrigger canoe has the same basic form as a dugout with the addition of either one (single outrigger) or two (double outrigger) steadying struts on either side, to assist the stability and buoyancy of the vessel (Davidson 1935:9).

4 The origin of this word is unclear, as it does not appear in either the Lardil or the Kaiadilt dictionaries.
} 
dugout canoes replaced nets and walbas as the primary method of catching dugong in the Wellesley Islands. ${ }^{5}$ There are a number of possible benefits to the whap and dugout canoe technique. Memmott (2010:43) noted that rafts were 'not very stable' and became waterlogged within a few hours of paddling (cf. Trigger 1987:80). Whaps and dugouts also required fewer participants for hunting while yielding a high rate of return. ${ }^{6}$ In the Croker Island region off the coast of north-west Arnhem Land, archaeological evidence indicates that the introduction of dugout canoes (replacing bark canoes) was followed by a notable presence of dugong and turtle remains when compared with the period immediately preceding it (Peterson 2005:430).

On Mornington Island, the reliability of the hunting method became increasingly important as large numbers of Aboriginal people became sedentary around the mission and dependent on its food supply (Dalley and Memmott 2010:122). At the same time, there were also instances where Aboriginal people used mission equipment to hunt for dugong, the proceeds of which they then hid for their own consumption (Wilson, 8 September 1920, 15 May 1921). ${ }^{7}$ Exercising personal autonomy in this way allowed individuals to meet their own responsibilities to kin through the provision of dugong meat. As more Aboriginal people learnt to build their own dugouts, they began approaching the mission with dugong and turtle meat that they had hunted themselves to exchange for flour, tea, sugar and other items such as fishing line and hooks (for example, Wilson, 1 December 1922).

Over the next 40 years, from the mid-1920s to the 1960s, hunting practices underwent little change. Aboriginal people on Mornington either used mission rowboats or manufactured their own dugout canoes and hunting materials using the techniques taught to them by Aboriginal staff from Cape York (Smart 1951:35). Gradually, the materials changed to include sharpened metal bolts in the thartha attached to rope and a light metal frame around the head of the whap (Marsh et al. 1980:258). In the 1960s, however, a significant shift occurred with the introduction and adoption of outboard motors and aluminium dinghies (Memmott 2010:92). One of the first such boats on Mornington was purchased by the artist Dick Roughsey, with money earned through the sale of his artworks

5 Reverend Wilson (24 June 1921, 22 December 1921), who replaced Hall in 1918, recorded instances where he destroyed canoes brought into 'prohibited waters' in proximity to the mission house. Wilson was concerned that fishing or cutting up dugong and turtle in these areas would attract sharks in the area where mission children swam for their daily bath.

6 Reverend Wilson recorded in his diary instances where the mission boat was sent out on hunting expeditions. With the exception of 1920, in the years 1919-25, the numbers of animals (dugong and turtle) caught were greater than the number of hunting expeditions.

7 Two of these recordings are as follows: 'The dinghy returned late last night with a nice dugong. I think William caught another + left it in the bush. There has been a general exodus in that direction this afternoon' (Wilson, 8 September 1920); and: 'Old man Peter's around cleared out on Friday with a dugong which William caught + planted. He got two + left the better one behind. I visited their plant + saw the remains' (Wilson, 15 May 1921). 
in Cairns in 1964 (Roughsey 1971:137). Although outboard motors increased the range and frequency of hunting activities by reducing the physical exertion required for paddling, they did require a large initial outlay for purchase and ongoing funds for fuel and general repair (Memmott 1979:308; Memmott and Trigger 1998:121). In 1976, 1977 and 1978, Marsh et al. (1980) visited Mornington Island and provided a detailed recording of dugong hunting methods. At that time they recorded that 'hunting is carried out from 4-5 $\mathrm{m}$ aluminium dinghies; outboard motors ranging in size from 9 to $40 \mathrm{HP}$ are used on all boats, the usual size being 18 to $25 \mathrm{HP}^{\prime}$ (Marsh et al. 1980:258). Dugong hunting methods were also shown in the Australian Museum film Dugong! Dugong!, recorded on Mornington Island in 1980 (Hughes 1980).

Between the 1960s and 1970s, Aboriginal people on Mornington moved into permanent, Western-style housing with electricity where the use of refrigerators and large freezers became possible (Brine 1980:4-5). While in principle these devices allowed meat to be preserved for longer and thus consumed by a single family over an extended period, the reality was somewhat more complex. Social responsibilities were such that hunters were still expected to share meat with others, particularly their family and the owners of the country from where the animal was taken. Other social conditions, such as the engagement of Mornington Islanders in employment on the Australian mainland, also mitigated against large numbers of dugong being caught (Marsh et al. 1980:264). Since that time gradual change has occurred, with larger boats and outboard motors becoming more common, and at the same time there has been (at least anecdotally) a decreasing reliance on bush foods for subsistence.

\section{Changes to Dugong Hunting and Native Title, 1990s-2004}

The impact and nature of change in hunting practice were brought to bear in native title proceedings. In 1996, Lardil, Kaiadilt, Yangkaal and mainland Ganggalida Aboriginal people lodged a native title claim over a large part of the seas of the southern Gulf of Carpentaria up to the high-tide mark on all of the Wellesley Islands and adjacent mainland coast (Behrendt 2004:14) (see Figure 15.1). The Lardil Peoples v State of Queensland [2004] FCA 298 (now referred to as the 'Wellesley Sea Claim') followed a similar successful determination in the Croker Island sea claim off the Arnhem Land coast (Mary Yarmirr and Others $v$ the Northern Territory of Australia and Others FCA 771) (Peterson 2005:428). The Croker case created an important legal precedent, which established the potential for Aboriginal marine tenure to be recognised in much the same way as Aboriginal land tenure. Part of this system of tenure was the requirement to 
ask permission to access sea country and to harvest marine resources within that country (Peterson 2005:438-9). It was this issue that played a similar role in the determination of the Wellesley Sea Claim. One avenue of questioning was about the changes in watercraft that had occurred in the Wellesleys during the mission period.

During the court process, lawyers for the State of Queensland, a respondent party to the claim, attempted to restrict the extent of the claim boundary by arguing that Aboriginal people had no knowledge of 'deep water'. Knowledge of 'deep water' beyond the inter-tidal zone, they argued, had arisen more recently with the advent of outboard motors and dugout canoes, which were better equipped than walbas to handle the rougher seas of deep water. Of particular importance to this line of questioning were those Aboriginal people who recalled the use of both walbas and dugout canoes. In this example, taken from the transcript of evidence, the lawyer for the State of Queensland questions a senior Yangkaal woman, Heather Toby, about changes in boat technology from about the 1920s.

When you were young you said how your father took you across from Forsyth to Denham on the raft, and you told us that you'd been fishing with your father on the raft when you were a young girl? Yes.

And I think you said that you generally stayed close in to the shore? Close to the shore.

And why is that? Well, he couldn't go any further because the sea gets rough.

And the raft is not safe out that far? It's not safe.

What about a canoe? Is a canoe any better for going out into the deep water? Oh yes. (Transcript, 23 September 1999:437)

While not ignoring the impact of technological change, lawyers for the Aboriginal claimants argued that the notion of hunting as a practice remained consistent with Aboriginal tradition. This argument mirrored comments made in an earlier court case, Yanner $v$ Eaton [1999], lodged by Ganggalida man Murrandoo Yanner who was also one of the claimants in the Wellesley Sea Claim. The dispute, which was resolved in the High Court of Australia on appeal, concerned the legality of Yanner's hunting of a crocodile - a protected species under Queensland's Fauna Conservation Act 1952 (Nicholls 2000). Although the case was as much about legal jurisdiction as the notion of tradition in native title rights, a number of comments were made during the court hearing regarding technological change in hunting. During the original trial in 1995, Dr David Trigger, an expert witness appearing on behalf of the defendant (Yanner), spoke about changes in boat and harpoon technology through the southern Gulf during the twentieth century 
(Trigger 1996:26-7). In the High Court finding, the judge noted that 'although traditional hunting methods had changed over the years, the way in which the appellant [Yanner] hunted crocodiles was pretty much the same as the way his ancestors had' (Nicholls 2000:145).

In the Wellesley Sea Claim determination, however, Justice Cooper (2004:119) noted that 'with the present day availability of powered boats, particularly aluminium dinghies with outboard motors, access to sea Country for fishing and hunting is now more readily available than in times past'. He also noted that 'hunting of these animals [dugong and turtle] has continued throughout the recorded history of each of these peoples and it continues today' (Cooper 2004:125). Justice Cooper granted non-exclusive rights to the Aboriginal applicants within an area smaller than that originally claimed (see Figure 15.1) (Cooper 2004:107, 131). This did not include most of the area within the claim boundary where the water is greater than $15 \mathrm{~m}$ deep and thus considered 'deep water' (Cooper 2004:133). In spite of this, the non-exclusive rights included formal recognition of the Aboriginal right to hunt dugong and turtle within the designated Wellesley Sea Claim area (Cooper 2004:137), which was important for the Aboriginal claimants as it gave legal recognition to their own notions of ownership (Carpentaria Land Council Aboriginal Corporation 2006:13-15).

\section{Dugong Hunting and Conservation Biology Discourses}

The Wellesley Sea Claim determination occurred during a period of intensified interaction between Aboriginal people and the Australian Government in the management of land and sea resources (Buchanan et al. 2009). Over this same period, there has been increased media scrutiny of Indigenous hunting, particularly in northern Queensland. These reports have included alleged incidences of cruelty by Aboriginal hunters, the supposed sale of dugong and turtle meat on the 'black market' and examples where dead animals were found drowned in nets (for example, Bateman 2010; Schwarten 2010; Tapim 2011). Reports of this nature have led a range of politicians, media personalities and conservation organisations (sometimes including Indigenous people) to call for limits or bans on the taking of protected species (for example, Michael 2007; Ryan 2010; Viellaris 2009). Sometimes public comment has followed the release of research papers in conservation biology implicating Indigenous hunting in the decline of dugong populations.

Much of the conservation biology discourse coalesces around estimates of dugong populations and modelling of what might constitute a sustainable harvest of such populations (Heinsohn et al. 2004; Marsh et al. 1997, 1999, 2004). Despite 
considerable advances in understandings of dugong biology and reproduction, accurate quantifying of dugong populations remains problematic. Factors that influence survey methodology include

- reliance on aerial surveys that count only a fraction of the actual population in any location

- discrepancies in the mathematical model applied to extrapolate from aerially visible dugongs to the actual population

- mass dugong migrations across large geographic regions

- fluctuations of local populations based on a range of other unknown factors (Heinsohn et al. 2004:417; Kwan et al. 2006:169; Marsh et al. 1980, 2004:436-7).

In an earlier publication, Marsh (1996:139) concluded that 'unfortunately, existing survey methods are too inaccurate and imprecise to monitor dugong numbers at spatial and temporal scales useful to management ${ }^{\prime}{ }^{8}$ Just as populations have been difficult to quantify, so too has the impact of Indigenous hunting on dugong populations. In Torres Strait, for example, Kwan et al. (2006:169) noted that depending on the population modelling used, 'over harvest is difficult to prove empirically with the data available' (see also Heinsohn et al. 2004:417). Sustainable Harvest of Marine Turtles and Dugongs in Australia-A national partnership approach (Marine and Coastal Committee 2005) listed the negative impacts on dugong and turtle populations as including by-catch across a range of fishing activities, predation of turtle eggs by native and introduced species, coastal development, deteriorating water quality, marine debris, loss of habitat, boat strike and poaching by foreign nationals in Australian waters. Despite this, the disproportionate amount of academic research and media reports examining Indigenous hunting continues to position it as the major variable impacting the sustainability of dugong populations. As Yanner (2008:4) and others have noted, there has been much less willingness to discuss the impact or regulation of industries that negatively impact on dugongs, particularly commercial fishing.

Perhaps the most problematic aspect of some of the conservation biology literature, however, is that it misunderstands or misrepresents Aboriginal perspectives on hunting. For example, in a recent paper, the Aboriginal community of Hopevale on eastern Cape York was selected as a case study for a number of reasons, including that the thinking of both Aboriginal community members and management agency staff were likely to be representative of the entire Cape York region' (Nursey-Bray et al. 2010:370). This rendering of Aboriginal people and their perspectives on hunting as homogenous across a large geographical region ignores the diversity of historical and contemporary

8 Academics from other disciplines, such as archaeology, are also beginning to challenge the efficacy of such approaches, using data obtained from their own investigations (for example, McNiven and Bedingfield 2008). 
experiences. As I have shown in the Mornington Island example, these factors are formative in developing Aboriginal perspectives on hunting, and, perhaps more importantly, impacting on hunting practice itself.

One of the Australian Government's responses to concerns about species sustainability has been to fund Aboriginal ranger groups across northern Australia. The 'Working on Country' program commenced in $2008^{9}$ and its priorities were

- protecting biodiversity and natural icons

- protecting and rehabilitating coastal environments and critical aquatic habitats

- supporting natural resource management in northern Australia

- enhancing community skills, knowledge and engagement (Department of the Environment, Water, Heritage and the Arts 2008).

More broadly, the program aimed to 'train and employ up to 300 Indigenous Rangers to manage and conserve the natural and cultural features of Indigenous lands and waters' (Commonwealth of Australia 2008:44). The program identified three priorities, the second of which sought to support Indigenous people to undertake work to identify, conserve, maintain and manage sea country, threatened species and their habitats and culturally or regionally significant species and their habitats (Department of the Environment, Water, Heritage and the Arts 2008). One group to receive funding from Working on Country was the Wellesley Islands Rangers based on Mornington Island (Department of the Environment, Water, Heritage and the Arts 2008).

\section{Wellesley Islands Rangers, Hunting and the Natural Resource Management Economy}

The earlier success of the Wellesley Sea Claim in recognising Aboriginal native title rights aided the application of the Carpentaria Land Council Aboriginal Corporation (CLCAC) for Australian Government funding from the Working on Country grants program (Department of the Environment, Water, Heritage and the Arts 2008). In round three (funding commencing in 2008) of the Working on Country program, the CLCAC Wellesley Islands Rangers received funding to implement the Thuwathu/Bujimulla Sea Country Plan (CLCAC 2006). The

9 'Working on Country' is the Indigenous-specific program within the larger 'Caring for Our Country' program. 
Sea Country Plan was devised by the Traditional Owners in collaboration with the CLCAC, and, amongst other things, prioritised the ongoing monitoring and sustainable use of dugong and sea turtle (CLCAC 2006:29-30).

Mornington Island is similar to most large, very remote Australian Aboriginal communities in that over the period of research (2007-09), very few Aboriginal Mornington Islanders were engaged in employment (Francis 2010). ${ }^{10}$ In 2006, the median weekly income on Mornington Island was \$209 (ABS 2006:Table B02), compared with the broader Australian median of $\$ 466$. Prior to gaining employment as rangers, most of the eight men had been engaged two days per week as 'participants' in the Community Development Employment Projects (CDEP) scheme (Interview, Wellesley Islands Rangers, 19 June 2009). CDEP is fully funded by the Australian Government and on Mornington Island consists of a number of 'work gangs': groups of men undertaking basic tasks such as rubbish removal, fencing or general carpentry jobs around the community. ${ }^{11}$ When employed in the ranger program, the men went from earning less than $\$ 200$ per week in CDEP to more than \$500 per week (Interview, Wellesley Islands Ranger A, 19 June 2009). This pay increase and the integration of the eight Mornington Island men into the natural resource management economy have had transformative social and economic effects on those men and their immediate families, as well as the broader community.

The most obvious of these changes has been the purchase of motor vehicles, with four of the eight rangers able to purchase a car or an additional car between 2008 and 2010 (Interview, Wellesley Island Rangers, 19 June 2009; Wellesley Islands Ranger B, Personal communication, 2010). On Mornington Island, owning a car, particularly a four-wheel-drive, facilitates access to remote parts of the Island, enabling families to travel the sometimes large distances 'out bush' to their traditional country to renew links, access bush food and participate in family activities. This is seen as particularly useful for many of the men who have large families with numerous young children. During a 2009 interview, the Rangers also commented on how they had greater capacity to afford 'household things' such as flat-screen TVs and freezers (Interview, Wellesley Island Rangers A, C and D, 19 June 2009). The men were also able to purchase items when they left the Island on work trips such as training exercises and ranger exchanges to other parts of Australia.

10 Although the 2006 Census recorded that more than 30 per cent of the Mornington Island community was employed, either in full-time or part-time positions, it seems likely that this figure includes CDEP participants (ABS 2006:Table B41). Although CDEP participation was not considered employment in the 2006 Census, my own experience suggests that Aboriginal Mornington Islanders would have been unlikely to make this distinction in completing the Census form. Taking into account the Mornington Shire Council's estimate of 60 full-time-equivalent positions in 2010 (Francis 2010), a more accurate estimation of fully funded employment (that is, excluding CDEP) might be 5-10 per cent of the total population of Mornington Island.

11 The program does include some women, particularly in a sewing 'gang'; however, the number of male participants greatly outweighs the number of women by my estimation at a ratio of three to one. 
In 2009, the female partners of some of the Rangers also noted a decrease in reliance on other family members to loan them money between pay weeks (Interview, 12 June 2009). Despite the expenditure on large items such as cars and boats, all the Rangers and their partners also noted a greater access to cash and saving: 'we just got money sitting there all the time' (Interview, 12 June 2009; also Interview, Wellesley Islands Ranger E, 19 June 2009). This 'ready money' (Merlan 2009:277) was seen as particularly useful for unexpected costs, such as trips to the mainland for medical treatment or school trips off the Island for the Rangers' children. As well as economic benefits, the Rangers' partners commented on how the men's involvement created social cohesion because of their shared experience of work and greater economic prosperity. This meant that 'you don't have to...[hold a] grudge against families and [worry] who's better than who in the group because of one fella bought this and that, or they saving more money than this person' (Interview, 12 June 2009).

The type of work undertaken by the Rangers was seen to have broader community benefits. When undertaking work around the islands, one ranger noticed that 'if we do that then our countrymen from that area feel proud of us, for what we done for them, in their country' (Interview, Wellesley Islands Ranger F, 19 June 2009). Much of this work involved patrolling sea country, undertaking tasks such as observing dugong populations, recording turtle nesting sites, recording seagrass habitats and removing potential threats to dugong and turtle such as discarded commercial fishing nets known as 'ghost nets' (Wilson n.d.:3). Some of these tasks were undertaken in collaboration with researchers and external agencies that travelled to the Wellesley Islands to work with the Rangers. The Rangers also sometimes undertook hunting for funerals (for example, Field notes, 23 August 2007, 3 March 2010) or important community events such as the Gulf Dance Festival (for example, Field notes, 22 September 2008). When the ranger program first commenced on Mornington Island, parents sometimes reported that their children wanted to become a 'Bush Ranger' or a 'Power Ranger' - two of the nicknames given to the Wellesley Islands Rangers. The main attractions of the job were the access to cars, boats and quad bikes, wearing a uniform, ${ }^{12}$ time spent out 'on country', trips off the Island and the derived income. Thus, as Buchanan et al. (2009:59) also concluded in their study of the Bardi Jawi Aboriginal Rangers in Western Australia, the social and economic benefits of being employed as a ranger were inextricably linked.

At the same time, there were undoubtedly discontinuities, which arose between governments' and the Wellesley Islands Rangers' discourses on hunting. Many of the Rangers' concerns relating to hunting pertained to the social mediation

12 Between 2007 and 2010, the Rangers were the only predominately Aboriginal positions that had an associated uniform. On the few occasions when the Rangers wore their uniforms, they were often described as 'too deadly' (impressive). 
of practice and the move away from 'traditional' methods of hunting. One such example was the perception that some hunters, particularly young men, hunted in order to demonstrate their masculinity. The Rangers disliked the notion of 'big-noting yourself for hunting, want to be the main man, you want to be the gun player, you want to catch more dugong, more turtle than the next fella next to you...It's not about that' (Interview, Wellesley Islands Ranger F, 19 June 2009). The desire to undertake hunting for social status was partly attributed to greater access to larger, more powerful boat engines in recent decades: 'Now that we got outboards and big speedboats, some fellas think that they're ironman' (Interview, Wellesley Islands Ranger B, 19 June 2009).

At the same time, the rise in notoriety of an individual as a skilled hunter was seen as detracting from the communality of sharing meat among a large number of people: 'Hunters before just put one in a canoe cause that's all they could fit... That one would feed nearly the whole village. Those days, they used to cut it up traditional way where under the traditional way, it shares out a lot of meat and it was fair' (Interview, Wellesley Islands Ranger F, 19 June 2009). The Rangers described how some hunters eschewed this 'fairness':

[T] here is some fellas on Mornington that kill today, they'll kill tomorrow, kill the next day and they'll kill the next day. They won't even give me or anyone else the chance to go. They've got two/three freezer full and they won't share it to the next-door neighbour or the bloke across the street. (Interview, Wellesley Islands Ranger F, 19 June 2009)

This was countered by the Rangers' use of contrary defining statements describing their own hunting practice, such as 'it's not about greed' and 'we share our meat' (Interview, Wellesley Islands Rangers F, 19 June 2009). Comments of this nature illustrated how the social responsibilities of hunting, particularly the distribution of meat, were particularly important to the Rangers.

When it came to implementing measures that might alter hunting practice, such as the adoption of a quota system to limit the number of dugongs killed, the Rangers were circumspect. One noted how changes to the current arrangements might be interpreted:

[I]t is going to be hard to enforce because this is their comfort zone, this is what they've been doing for a long time, they're too used to it. They going to say, 'you can't tell me what to do!' But we say 'it's not telling you what to do, it's about managing it'. (Interview, Wellesley Islands Ranger F, 19 June 2009)

At the same time, they noted that the resource was important and that 'we need those things to be there for our grandchildren and great-grandchildren'. In the meantime, the Rangers undertook catch monitoring, surveyed dugong and 
turtle populations and talked in generalities about changing hunting practices in the future. ${ }^{13}$ One described the approach as 'we just keep an eye on things' (Interview, Wellesley Islands Ranger A, 19 June 2009), but would not be drawn on what situations might require particular intervention.

The adoption of this kind of language might be considered as an example of Babidge et al.'s (2007:154) concept of 'management speak'. 'Management speak' is defined as a form of dialogue used by Aboriginal people when engaged in discussions over resources. In a candid interview in 2008, Murrandoo Yanner explained the problematic association between employment in the natural resource management economy and the adoption of particular approaches to dugong management. He (2008:5) noted:

$[\mathrm{P}]$ rovided that we deliver on the environmental outputs we can say what we want politically, such as the dugong stuff, [we might say] 'We're not regulating dugongs, regardless of what government policy [is]'. But we can't say that because only the government is funding our rangers. ${ }^{14}$ So we need to seek funding elsewhere so we can be staunch and make up our own minds and say what we want without the government jerking the chain on our neck.

Yanner's position and the Wellesley Islands Rangers' use of 'management speak' when discussing dugong management are also suggestive of Martin's use of the term 'strategic engagement'. For Martin (2003:8), strategic engagement is the 'process through which indigenous individuals, groups and communities are able to interact with, contribute to, draw from - and of course reject - the formal and informal institutions of the dominant Australian society'. Thus, the Rangers might be seen to benefit economically and socially from their involvement in the ranger program and undertake some works towards the overall goal of dugong management. At the same time, their own discourse about hunting focuses on the social and cultural changes to hunting rather more so than a conservation biology approach.

\section{Conclusion}

Through this chapter, I have charted the history of dugong hunting on Mornington Island as an intercultural practice, in much the same way that Merlan proposed. The arrival of missionaries and Cape York staff in the region in 1914 had a transformative impact on the techniques and material culture

13 This approach included involvement in seagrass habitat surveys - for example, Taylor et al. (2007:i).

14 It is unclear here what Yanner meant by 'our rangers', however, it might refer to the Wellesley Islands Rangers and the Moungabi (Burketown) Rangers, who are both auspiced by the CLCAC with which Yanner was closely associated. Alternatively, it might relate to all Indigenous rangers. 
of dugong hunting. Observable changes also occurred from the 1960s with the introduction of aluminium dinghies and outboard motors. Through these periods of change, the sentiment of sharing dugong meat has persisted, while the number of people actually involved in a single hunt has decreased. The development of hunting through time is such that "it can no longer be seen simply as a "traditional subsistence practice" insofar as such a label resists critical examination of contemporary intersecting values and resource streams' (Merlan 2009:278).

These intersecting values have come to the fore in the more recent period when the monitoring of dugong populations has become an integral part of the work of eight Aboriginal rangers based on Mornington Island. The program has had obvious economic and social benefits for the Rangers and their families. In employing the notion of 'strategic engagement' (Martin 2003) though, I have sought to explore the differing priorities of the Rangers and the Australian Government which employs them in much the same way that Yanner did. While Aboriginal people take up employment with agencies funded by the Australian Government, they do so with their own interpretations of key issues, as exemplified by the example of dugong hunting and management.

One question that remains, however, is the degree to which the adoption of 'management speak' and the mediation of governmental concerns might be considered strategic in the long term. As Martin (2003:8) noted, "'strategic engagement" should give Indigenous individuals and collectives...real choices as to where to go, and how to get there'. Looking to the future is a clear component in the successful implementation of strategic engagement. In the future it seems likely that governments, both State and Federal, are likely to desire more rather than less regulation of dugong hunting, particularly if dugong populations show continuing decline. Should this occur, the Rangers will have to develop new strategies for engaging with governments, particularly given that in other parts of Australia quota systems and/or bans on hunting have been established. Management speak has been utilised in the short term to mediate differing notions of dugong management, but in the absence of actual change to hunting practice, its effectiveness as a long-term strategy seems questionable.

One proposed solution has been for Aboriginal people to move away from government funding of ranger programs. In this scenario, Aboriginal people would enter into partnerships with private entities - to again quote Yanner (2008:5): 'so we're looking more at working with large companies and getting our own funding.' This approach is somewhat reminiscent of Altman's model of a hybrid economy where interaction might occur between the 'market', the 'state' and Aboriginal 'customary' realms. Yanner has suggested that this approach might provide Aboriginal people with the economic autonomy to make their own decisions in the management of country. This notion of attaining an autonomous 
decision-making position might be difficult to achieve given the embeddedness of Aboriginal people in the intercultural milieu, where rights and interests in natural resources are interconnected. As Smith (2003:88) concluded: 'Aboriginal people are neither truly autonomous in their relationship to wider Australian society, nor successfully refashioned as participants in the wider economy.' Despite this, forays such as the ranger program provide Aboriginal people with opportunities to gain skills and experience, particularly in developing relationships with governments, which bode well for the development of innovative responses to complex management issues. In-depth studies and those that explore the historical trajectory of practices such as hunting have the potential to meaningfully explore the complex ways in which Aboriginal people experience and seek to mediate such relationships.

\section{References}

Altman, J. C. 1987. Hunter-Gatherers Today: An Aboriginal economy in north Australia. Canberra: Australian Institute of Aboriginal Studies.

Altman, J. C. 2001. Sustainable development options on Aboriginal land: the hybrid economy in the twenty-first century. CAEPR Discussion Paper No. 226, Centre for Aboriginal Economic Policy Research, Australian National University, Canberra.

Austin-Broos, D. 2003. Places, practices and things: the articulation of Arrente kinship with welfare and work. American Ethnologist 30 (1): 118-35.

Australian Bureau of Statistics (ABS) 2006. 20010 BCP Gununa (L)- Qld Urban Centre-Locality. Catalogue No. 2001.0, Community Profile Series. Canberra: Australian Bureau of Statistics.

Babidge, S., Greer, S., Henry, R. and Pam, C. 2007. Management speak: Indigenous knowledge and bureaucratic engagement. Social Analysis 51 (3): 148-64.

Bateman, D. 2010. State must do more to protect dugongs. Cairns Post, 29 April 2010: 11 .

Behrendt, J. 2004. Lardil People v State of Queensland [2004] FCA 298. Indigenous Law Bulletin 6 (2): 14-17.

Blake, T. 1998. Historical report Wellesley Islands Sea Claim. Unpublished report prepared for the Carpentaria Land Council and the Claimants, Brisbane. 
Indigenous Participation in Australian Economies II

Bradley, J. J. 1997. Li-anthawirriyarra, people of the sea: Yanyuwa relations with their maritime environment. Unpublished PhD thesis, Faculty of Arts, Northern Territory University, Darwin.

Brine, J. 1980. After Cyclone Ted on Mornington Island: the accumulation of physical and social impacts on a remote Australian Aboriginal community. Disasters 4 (1): 3-10.

Buchanan, G., Altman, J., Arthur, B., Oades, D. and the Bardi Jawi Rangers 2009. 'Always part of us': the socioeconomics of Indigenous customary use and management of dugong and marine turtles - a view from Bardi and Jawi sea country, Western Australia. Research Report Knowledge Series 001, North Australian Indigenous Land and Sea Management Alliance, Charles Darwin University, Darwin.

Carpentaria Land Council Aboriginal Corporation (CLCAC) 2006. Thuwathu/ Bujimulla Sea Country Plan: Aboriginal management of the Wellesley Islands region of the Gulf of Carpentaria. Burketown, Qld: Carpentaria Land Council Aboriginal Corporation.

Cawte, J. 1972. Cruel, Poor and Brutal Nations: The assessment of mental health of an Australian Aboriginal community by short-stay psychiatric field team methods. Honolulu: University of Hawai'i Press.

Commonwealth of Australia 2008. Caring for Our Country: Outcomes 2008-2013. Canberra: Commonwealth of Australia.

Cooper, J. 2004. Determination of Lardil, Kaiadilt, Yangkaal and Gangalidda Peoples v State of Queensland \& Others [2004] Federal Court of Australia 298. Federal Court of Australia.

Dalley, C. and Memmott, P. 2010. Domains and the intercultural: understanding Aboriginal and missionary engagement at the Mornington Island Mission, Gulf of Carpentaria, Australia from 1914 to 1942. International Journal of Historical Archaeology 14: 112-35.

Davidson, D. S. 1935. The chronology of Australian watercraft. The Journal of the Polynesian Society 44 (173): 1-16; 44 (174): 69-84; 44 (175): 137-52; 44 (176): 193-207.

Department of the Environment, Water, Heritage and the Arts 2008. Caring for Our Country - Working on country. Canberra: Australian Government. Viewed 10 June 2010, <http://www.nrm.gov.au/funding/2008/woc.html> 
Francis, C. 2010. Indigenous economic development: challenges for traditional owners, council and community. Paper presented at the Aligning Indigenous Land Management and Economic Development Conference, Darwin, 24 March 2010.

Gudeman, S. 2001. The Anthropology of Economy: Community, market and culture. Oxford: Blackwell.

Hall, R. H. 1914-17. Diaries. Unpublished copies of personal diaries held at the Hibberd Library, Weipa, Qld.

Hall, R. H. 1986 [1914-17]. A Missionary Pioneer: Robert Hall of Mornington Island. His diaries. R. Ian Hall (ed.). Waihola, New Zealand.

Harrison, J. 1974. Missionaries, fisheries and government in far north Queensland 1891-1919: a study of conflict and co-operation between the Presbyterian mission stations, commercial fishing interests and the Queensland Government on matters concerning the welfare of the Aborigines in Cape York and the Torres Strait 1891-1919. Unpublished BA(Hons) thesis, University of Queensland, St Lucia.

Heinsohn, R., Lacy, R. C., Lindenmayer, D. C., Marsh, H., Kwan, D. and Lawler, I. R. 2004. Unsustainable harvest of dugongs in Torres Strait and Cape York (Australia) waters: two case studies using population viability analysis. Animal Conservation 7: 417-25.

Hinkson, M. and Smith, B. 2005. Introduction: conceptual moves towards an intercultural analysis. Oceania 75 (3): 157-66.

Holcombe, S. 2005. Luritja management of the state. Oceania 75 (3): 222-33.

Howard, R. B. 1910. Annual Report of the Chief Protector of Aboriginals for 1910, Queensland. Brisbane: Government Printer.

Hughes, H. 1980. Dugong! Dugong! [Video recording.] Australian Museum film series, Sydney.

Hunt, J., Altman, J. C. and May, K. 2009. Social benefits of Aboriginal engagement in natural resource management. CAEPR Working Paper No. 60, Centre for Aboriginal Economic Policy Research, Australian National University, Canberra.

Kwan, D., Marsh, H. and Delean, S. 2006. Factors influencing the sustainability of customary dugong hunting by a remote indigenous community. Environmental Conservation 33 (2): 164-71. 
Indigenous Participation in Australian Economies II

Loos, N. 1982. Invasion and Resistance: Aboriginal-European relations on the north Queensland frontier 1861-1897. Canberra: Australian National University Press.

McKnight, D. 1999. People, Countries and the Rainbow Serpent. Oxford: Oxford University Press.

McNiven, I. J. and Bedingfield, A. C. 2008. Past and present marine mammal hunting rates and abundances: dugong (Dugong dugon) evidence from Dabangai bone mound, Torres Strait. Journal of Archaeological Science 35: 505-15.

Marine and Coastal Committee 2005. Sustainable Harvest of Marine Turtles and Dugongs in Australia-A national partnership approach. Canberra: Natural Resource Management Ministerial Council.

Marsh, H. 1996. Progress towards the sustainable use of dugongs by Indigenous peoples in Queensland. In M. Bomford and J. Caughley (eds), Sustainable Use of Wildlife by Aboriginal Peoples and Torres Strait Islanders, pp. 139-66. Canberra: Australian Government Publishing Service.

Marsh, H., Eros, C., Corkeron, P. and Breen, B. 1999. A conservation strategy for dugongs: implications of Australian research. Journal of Marine and Freshwater Research 50: 979-90.

Marsh, H., Gardner, B. R. and Heinsohn, G. E. 1980. Present-day hunting and distribution of dugongs in the Wellesley Islands (Queensland): implications for conservation. Biological Conservation 19: 255-67.

Marsh, H., Harris, A. N. M. and Lawler, I. R. 1997. The sustainability of the Indigenous dugong fishery in Torres Strait, Australia/Papua New Guinea. Conservation Biology 11 (6): 1375-86.

Marsh, H., Lawler, I. R., Kwan, D., Delean, S., Pollock, K. and Alldredge, M. 2004. Aerial surveys and the potential biological removal technique indicate that the Torres Strait dugong fishery is unsustainable. Animal Conservation 7: 435-43.

Martin, D. 2003. Rethinking the design of Indigenous organisations: the need for strategic engagement. CAEPR Discussion Paper No. 248, Centre for Aboriginal Economic Policy Research, Australian National University, Canberra.

Michael, P. 2007. Elders unhappy over dugong, turtle slaughter. The CourierMail, 9 October 2007: 7. 
Memmott, P. 1979. Lardil properties of place: an ethnological study in manenvironment relations. Unpublished PhD thesis, University of Queensland, St Lucia.

Memmott, P. 1983. Social structure and the use of space amongst the Lardil. In N. Peterson and M. Langton (eds), Aborigines, Land and Land Rights, pp. 33-65. Canberra: Australian Institute of Aboriginal Studies.

Memmott, P. 2010. Material culture of the North Wellesley Islands. AIATSIS Research Report Series, Aboriginal and Torres Strait Islander Studies Unit, University of Queensland, St Lucia.

Memmott, P. and Trigger, D. 1998. Marine tenure in the Wellesley Islands region, Gulf of Carpentaria. In N. Peterson and B. Rigsby (eds), Customary Marine Tenure in Australia, pp. 110-24. Oceania Monograph 48. Sydney: University of Sydney.

Merlan, F. 1998. Caging the Rainbow: Place, politics and agency in a north Australian town. Honolulu: University of Hawai'i Press.

Merlan, F. 2005. Explorations towards intercultural accounts of socio-cultural reproduction and change. Oceania 75 (3): 167-82.

Merlan, F. 2006. European settlement and the making and unmaking of Aboriginal identities. The Australian Journal of Anthropology 17 (2): 179-95.

Merlan, F. 2009. Introduction: recuperating economic anthropology. The Australian Journal of Anthropology 20: 269-84.

National Native Title Tribunal. 2005. Native Title Determination: QC96/2 QG207/97 (Wellesley Islands Sea Claim). Map created by Geospatial Services, National Native Title Tribunal. Canberra: NNTT.

Nicholls, F. G. 2000. Aboriginal hunting rights and fauna protection legislation. Environmental Policy and Law 30 (3): 143-6.

Nursey-Bray, M., Marsh, H. and Ross, H. 2010. Exploring discourses in environmental decision making: an Indigenous hunting case study. Society \& Natural Resources 23: 366-82.

Peterson, N. 2005. On the visibility of Indigenous Australian systems of marine tenure. Senri Ethnological Studies 67: 427-44.

Roughsey, D. (Goobalathaldin) 1971. Moon and Rainbow: The autobiography of an Aboriginal. Brisbane: Rigby Books. 
Indigenous Participation in Australian Economies II

Ryan, B. 2010. MP attacks calls for dugong cruelty crackdown. ABC News, 21 December 2010.

Schwarten, E. 2010. Crackdown on illegal dugong hunting demanded. Australian Associated Press General News, 28 April 2010.

Smart, P. 1951. The dugong. Walkabout 17 (11): 34-5.

Smith, B. R. 2003. Pastoralism, local knowledge and Australian Aboriginal development in northern Queensland. The Asia Pacific Journal of Anthropology 4 (1-2): 88-104.

Stanner, W. E. H. 1979 [1958]. Continuity and change among the Aborigines. In W. E. H. Stanner (ed.), White Man Got No Dreaming, pp. 41-66. Canberra: Australian National University Press.

Tapim, F. 2011. Call to probe illegal dugong, turtle trade. ABC News, 6 September 2011.

Taylor, H. A., Rasheed, M. A. and Coles, R. 2007. Seagrass Communities of the Wellesley Island Group. Cairns, Qld: Queensland Department of Primary Industries and Fisheries.

Thompson, D. F. 1934. The dugong hunters of Cape York. The Journal of the Royal Anthropological Institute of Great Britain and Ireland 64 (July-December): 237-63.

Trigger, D. S. 1987. Inland, coast and islands: traditional Aboriginal society and material culture in a region of the southern Gulf of Carpentaria. Records of the South Australia Museum 20 (2): 69-84.

Trigger, D. S. 1996. Witness testimony of Dr David S. Trigger. Transcript of Graham John Eaton v Murrandoo Bulanyi Mungabayi Yanner, No. c/f 1692 of 1995, Magistrate's Court, Mount Isa, Qld: 21-32.

Viellaris, R. 2009. Crackdown urged on cruel trade in turtle, dugong meat. The Courier-Mail, 10 September 2009: 14.

White, F. D. 1994. Church and state in Presbyterian missions, Gulf of Carpentaria: 1937-1947. Unpublished MA thesis, University of Queensland, St Lucia.

Wilson, B. n.d. Dugong \& marine turtle project update. Carpentaria Land Council Aboriginal Corporation NRM Newsletter: 3.

Wilson, R. H. 1918-26. Diaries. Unpublished copies of personal diaries held at the Australian Institute of Aboriginal and Torres Strait Islanders Studies Library, Canberra. 
Yanner, M. 2008. Traditional owner comment. Native Title Newsletter 4 (July-August): 4-6. Canberra: Native Title Research Unit, Australian Institute of Aboriginal and Torres Strait Islander Studies.

\section{Acknowledgments}

Thanks to all Aboriginal research participants in the Wellesley Islands from 2006 to 2010, particularly the Wellesley Islands Rangers and their families. This research has been assisted by a grant, 'Fishing Through Time in the Wellesley Islands' (G2007/7292), from the Australian Institute of Aboriginal and Torres Strait Islander Studies. Additional assistance came from the Australian Research Council (ARC) Discovery Project 'Isolation, Insularity and Change in Island Populations - An interdisciplinary study of Aboriginal cultural patterns in the Gulf of Carpentaria' (DP0663047). The School of Architecture at the University of Queensland assisted with travel costs to attend the Indigenous Participation in Australian Economies Conference where this chapter was first presented. This chapter was further developed as a result of discussions with Geoff Buchanan of the Centre for Aboriginal Economic Policy Research (CAEPR) at The Australian National University and Dr David Martin. I extend particular thanks to Professor David Trigger, Wendy Asche, Dr Carla Meurk and Kelly Greenop for their comments on an earlier draft. 